\title{
Forecasting the Nigerian Gross Domestic Product in Correspondence to Crude Price Fluctuations
}

\author{
Siddhant Jhawar \\ Student at Daly College, Residency Area, Indore, Madhya Pradesh, 452001, India
}

\begin{abstract}
The study aims to find a long-run empirical correlation between crude prices and the Nigerian Economy. Therefore, the Independent Variable for the study is the natural log of crude prices and the Dependent Variable would be the economic activity in Nigeria (Operationalized using the natural log of GDP). The research explores the Vector Autoregression Model (VAR Model), Serial Correlation LM Test, VAR Granger Causality/Block Exogeneity Wald Tests, Forecast Error Variance Decomposition (FEVD), and the Impulse Response Functions (IRFs). The time period of the study was from 1998 to 2008 (annual statistics were used), and the findings from the Augmented Dickey-Fuller Unit Root Test indicates that lngdp is stationary for an optimal maximum lag of 1 in 1 st Level, including Intercept in the test equation. Furthermore, lngdp is found to have a causal impact on lncp. This finding is complemented by the findings of FEVD and the IRFs. The empirical analyses show that the lngdp is a strong determining factor of the lncp fluctuations and directly influences forecasts of the same, ceteris paribus. In the final analysis, the the researchers recommend that the Central Bank of Nigeria, while making policies relating to economic growth, should involve indicators of external commodity markets and should diversify from an oildependent economy to an economy which would be less susceptible to Dutch Disease.
\end{abstract}

Keywords:Statistical Analysis; Econometrics; Forecast Error Variance Decomposition; Impulse Response Functions

DOI: $10.7176 /$ RJFA/12-22-11

Publication date: November 30th 2021

\subsection{Introduction}

Nigeria is generally referred to as an 'Oil Economy' because of the country's large amount of oil reserves. Yet, the Petroleum Sector in Nigeria currently contributes to less than 10 percent of the country's GDP. 1 To these ends, the study analyzes the ramifications of changes in the market prices of the Crude Petroleum on the GDP. Furthermore, the study accounts for the cyclical nature of the commodity prices and compares it with the cyclical nature of the Nigerian GDP to find any possible lags in the time series of both sets of data. Economic cycles and fluctuations have an impact on each of the country's economic performance. 2 Economic development includes trends of economic growth and cycle that indicates the period when real development is different from the default trend. 3 Hamilton, Blanchard and Gali, viewed changes in the price of oil as an imperative source of economic fluctuations, in which the resultant effect led to global shock, capable of affecting many economic activities instantaneously.4 This shock is generally discerned to have a similar consequence due to events like fall in growth rate, high unemployment rate, or a high inflation rate, while the magnitude and the reasons of these shocks' effects may differ. While using the Impulse Response Functions, the sets of data (Appendix 4.0 Correlational Analysis, Table 1) showed that a one standard deviation $(\sigma)$ shock, impulse, or innovation given to lncp will result in a decrease in lngdp until the 2nd period, whereas from the 2nd period forth it would result in an increase in the lngdp. For an import-dependent economy, a surge in the crude price will lead to shock in the economy, vice versa for an export-dependent economy. Wherein, Nigeria adheres to the latter case.

There are many established empirical analyses on the macroeconomic consequences of oil price shocks to net exporting countries, this is based on the dependency between oil price and the business cycle which can be explained through the impact of the oil price shocks on aggregate demand.4 Economists opine that an increased crude price would reduce the national real output by initially causing a decrease in the aggregate supply. Since higher energy (raw material in an economic, production process) prices imply that firms will purchase less energy, and the quantity demanded of energy by the firms can be assessed by an analysis of the Price Elasticity of Demand of energy in the market and the \% $\mathrm{\Delta Price}$. Consequently, the productivity - operationalized as the efficiency of the production of a good or service expressed using a ratio of the output created by the number of inputs involved in the production process - of any given volume of capital and labor would diminish and cause a loss of potential real output. The aforementioned changes in the economic conditions, without exception, would cause a decrease in the numbers of factors of production and real wages. The following negative spiral would engender a leftward shift in the Aggregate Demand.

\subsection{Rationale Behind the Study}

As a result of the author's awareness of the significance of fluctuations of crude oil prices on the economic growth of the 'Oil Economy',1 the brainwave to execute this study emerged. External supply-side shocks have the ability 
to adversely affect international trade, consumption, as well as the investment injected into the economy. An increase in the crude prices can reduce trade deficits in the short-run and make a major contribution to the balance of payments, which is particularly relevant for developing economies, such as Nigeria. The primary purpose behind this research is to analyze the sole impact of crude oil price fluctuations on the GDP growth in Nigeria, ceteris paribus.

\subsection{Methodology}

The statistical models aim at exploring the correlation and trend existing between the crude oil prices on the nominal national output (GDP). The data employed is an annual measure of central tendency sourced from Statista and The World Bank. The data sets cover a time period of 1998 to 2008. All the variables are operationalized in United States Dollars (US\$). The Nigerian GDP acts as a proxy of the aggregate Nigerian economic activity. Before applying any time series, the statistical properties of the variables were tested to determine both the longrun and the short-run causal relationships and the summary of the statistics of all variables in this econometric analysis.

\subsection{Variables}

Independent Variable (IV) : Natural Logarithmic of Crude Oil Prices (denoted by 'Incp') Dependent Variable (DV) : Natural Logarithmic of Nominal GDP (denoted by 'lngdp')

\subsection{Estimation Procedure and the Selection of an Optimal Time Lag}

The ideal lag length must be determined in order to prevent overstating or understating the real amount of lag, as well as to avoid biased estimates of accepting the null hypothesis when it should be rejected, and vice versa. For instance, too many lags can cause a loss of degrees of freedom, statistically insignificant coefficients, and multicollinearity; whereas, too few lags can cause specification errors. A level VAR model of order is estimated using the largest possible order of the integration of the basic variables and the ideal lag length, and zero restrictions tests are performed on lagged coefficients of the regressors up to the optimal lag. The study used Time Series data; therefore, it was ensured that all data collected was on an annual basis. The statistical analysis used the Ordinary Least Squares (OLS) to estimate the parameters. Cointegration techniques were used to evaluate the relationship between crude oil prices and the economic growth in Nigeria. The Vector Autoregressive Model (VAR) and Variance Decomposition Model were utilized so that they provide estimates of both the short-run and long-run. If variables are not stationary, co-integration between variables is found to occur and refuses to die off after taking their first difference (Setargie, 2015).

Since the dependence of the DV on the IV is rarely instantaneous, the DV, very often, responds to the IV with a lapse of time (lag).

The study utilised LR: Sequentially modified LR test statistic, FPE: Final Predict Error, AIC: Akaike Information Criterion, SC: Schwarz Information Criterion, and HQ: Hannan-Quinn Information Criterion to deduce the optimal lag $(\mathrm{k})$ for the assessment of the VAR Model. Since the maximum minimizations occur at the second lag length, and FPE and AIC are better choices for smaller samples, the proposed $\mathrm{k}=1$.

The Optimal Lag Selected is Lag 1. (Appendix 4.2.1 and Appendix 4.2.2).

\subsection{Vector Auto Regression (VAR) Model}

The objective of the analysis is to identify the interdependencies between the variables, namely Gross Domestic Product (lngdp) and Crude Prices (lncp). Each variable in the model is stated as independent in the specification as a function of its latency and the lag of other variables in the model. In other words, the DV is a function of its lagged values and the lagged values of the IV in the model. The model takes into consideration 2 independent, exogenous error terms, which are $\varepsilon \boldsymbol{\Xi}_{1 t}, \varepsilon \boldsymbol{\Xi}_{2 t}$. These stochastic error terms are interpreted as structural innovations, impulses, or shocks. Interpretation of the Short Run coefficients is as in any other linear model: they are ceteris paribus effects and inference can be based on the usual ordinary least square method (OLS) standard errors and test statistics.

$$
\begin{aligned}
& \ln g d p_{t}=\alpha+\sum_{i=1}^{k} \beta_{i} \ln g d p_{t-i}+\sum_{j=1}^{k} \gamma_{j} \ln c p_{t-j}+\varepsilon_{1 t} \\
& \ln c p_{t}=\delta+\sum_{i=1}^{k} \beta_{i} \ln c p_{t-i}+\sum_{j=1}^{k} \gamma_{j} \ln g d p_{t-j}+\varepsilon_{2 t}
\end{aligned}
$$

(Appendix 4.3). Derived from the estimates are the following equations for the model: 


$$
\begin{gathered}
\operatorname{lng} d p=c(1) \cdot \ln c p+c(2) \cdot \ln g d p(-1)+c(3) \\
\operatorname{lncp}=c(4) \cdot \ln g d p+c(5) \cdot \ln c p(-1)+c(6)
\end{gathered}
$$

\subsubsection{Augmented Dickey-Fuller Unit Root Test on D[InGDP]}

Maximum Lags used for each condition were 1, but the Lag Length for each condition remained 0; the Selection Criterion was the Akaike Info Criterion (AIC). These stationarity tests were performed because there lies a need to estimate the maximum order of integration of the DV.

\subsubsection{In Level, Included in Test Equation: Intercept}

(Appendix 4.4.1). Because the Absolute Value of the Augmented Dickey-Fuller t-Statistic is lower than all the three absolute, test critical values, the null hypothesis stating ' $\ln (\mathrm{GDP})$ has a unit root' cannot be rejected at any given significance level.

\subsubsection{In Level, Included in Test Equation: Trend and Intercept}

(Appendix 4.4.2). Known is that the @Trend(“1998”) and the constant term is statistically significant. Because the Absolute Value of the Augmented Dickey-Fuller t-Statistic is lower than all the three absolute, test critical values, the null hypothesis stating 'In(GDP) has a unit root' cannot be rejected at any given significance level.

Therefore, in Level the series is non-stationary.

\subsubsection{In 1st Level, Included in Test Equation: Intercept}

(Appendix 4.4.3). Because the Absolute Value of the Augmented Dickey-Fuller t-Statistic is lower than only one of the three absolute, test critical values (at the 1\% significance levels), the null hypothesis stating ' $\ln (\mathrm{GDP}$ ) has a unit root' is to be rejected. Hence, in 1st Level and only when the constant is included as an exogenous, the series is stationary.

\subsubsection{In 1st Level, Included in Test Equation: Trend and Intercept}

(Appendix 4.4.4). Because the Absolute Value of the Augmented Dickey-Fuller t-Statistic is lower than two of the three absolute, test critical values (at $1 \%$ and $5 \%$ significance levels), the null hypothesis stating ' $\ln (\mathrm{GDP}$ ) has a unit root' cannot be rejected at any any level except the $10 \%$ significance level. Even though the Augmented Dickey-Fuller t-Statistic is weakly significant at the $10 \%$ level, the null hypothesis that $\ln (\mathrm{GDP})$ has a unit root is rejected at the $10 \%$ level.

Therefore, the $\ln (\mathrm{GDP})$ is only stationary in the 1 st Level with the Intercept included in the test equation. Therefore, in Level and with Intercept, the stationarity of the series implies that its mean, variance, and covariance are constant over time. In other words, the series is time invariant.

\section{Log Differenced LNGDP}

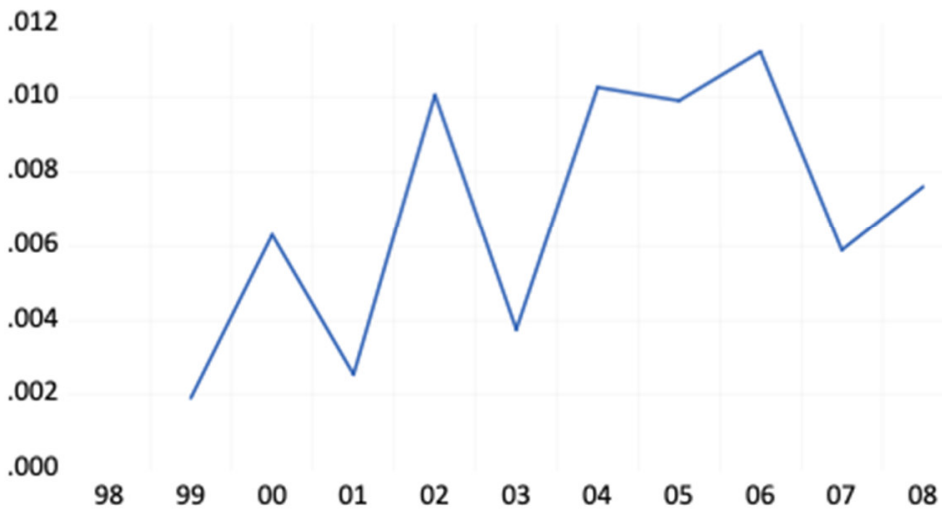

\subsection{VAR Residual Serial Correlation LM Tests}

The VAR residual serial correlation test is used before the assessment of the Forecast Error Variance Decomposition (FEVD) and Impulse Response Functions (IRFs) to ascertain the sufficiency of the lag selection criterion used in the evaluation of a chosen multivariate model. It is used to verify restrictions on an unbounded model, and it is based on the confined optimum likelihood test. From the Breusch-Godfrey Serial Correlation LM Test (Appendix 4.5), there is no serial correlation, which is the null hypothesis for the test. The findings show that there is no serial association, allowing the study to move forward with forecasting. This implies that the null 
hypothesis is not rejected.

\subsection{VAR Granger Causality/Block Exogeneity Wald Tests}

(Appendix 4.6.1 and Appendix 4.6.2). Known is that lngdp is the DV and at 5\% significance level, we fail to reject (accept) the null hypothesis that there is no causality between the lagged coefficients of the IV and those of the $\mathrm{DV}$; furthermore, the findings stipulate that the exogeneity of the DV is decided by several exogenous factors to the model.

However, the findings also show that when lncp is the DV, we can reject the null hypothesis because the probability of Chi-square is lower than 0.05 or an alternative approach is that the probability value of the F-statistic is lower than 0.05 , which implies that there lies a causality between the two variables.

Therefore, the lagged coefficients of lngdp have a causal impact on the lagged coefficients of lncp, and a plausible conclusion includes how the results invariably show that shocks in the economy (i.e. economic condition, which is operationalized using GDP) are a determining factor for the changes in the commodity markets (i.e. crude oil markets), since causality is noted.

\subsubsection{Forecast Error Variance Decomposition (FEVD) and Impulse Response Functions (IRFs)}

We generate forecast error variance decompositions (FEVD) and impulse response functions (IRF) from the calculated VAR Model, which are used to measure the dynamics of interrelationships, interactions, and the degree of causative relationships among the variables in the system. Variance decomposition divides variation in an endogenous variable and further into component shocks to the VAR Model, whereas impulse response functions track the implications of a shock to one endogenous variable on the VAR Model's other variables.

The VAR innovations can be linked in real time while modeling FEVD and IFRs. - i.e., a shock in one variable might have an influence on other variables due to their synchronous connection. Because shock to individual variables cannot be detected independently due to the contemporaneous correlation, the reactions of one variable to innovations in another variable of interest cannot be properly described in isolation.

To orthogonalise impulses and address this identification challenge, the study employed the Cholesky methodology, which utilizes the inverse of the Cholesky component of the residual covariance matrix. A prespecified causative ordering of the variables is required for the method to work.

\subsubsection{Forecast Error Variance Decomposition}

(Appendix 4.7, Appendix 4.8, and Appendix 4.9). The study utilized the Cholesky factorization and forecasted the variables upto 5 periods, which are equivalent to 5 years. Shocks in the predicted variable's residual contribute more to its variance than shocks in other variables in the initial period when predicting a variable. For instance, the shocks in the lngdp contributed more to its variance, $100.00 \%$, in the 1 st period, down to $98.64 \%$ in the 20 th period of the forecasted period. While the lncp contributions to the lngdp variance decomposition started at the 2nd period, $0.60 \%$, and increased with periods till the 5th periods, $1.36 \%$. Therefore, the decomposition shows that lncp has an impact on the lngdp volatility, and that in the future, lngdp will be responsive to lncp volatility, even though the contributions are statistically insignificant.

Whereas, the contributions of lngdp in the variance of lncp start from the 1 st period, $20.62 \%$, and increase till the 20th period, $95.54 \%$. The results imply that lngdp would account for a majority proportion of the contributions from the 3rd period, 51.87\%. Furthermore, till the 20th period, lngdp would be responsible for $95.54 \%$ of $\operatorname{lncp}$ volatility. Therefore, the results suggest that lngdp plays a statistically significant role in lncp fluctuations, and not vice versa. 


\section{Variance Decomposition using Cholesky (d.f. adjusted) Factors}
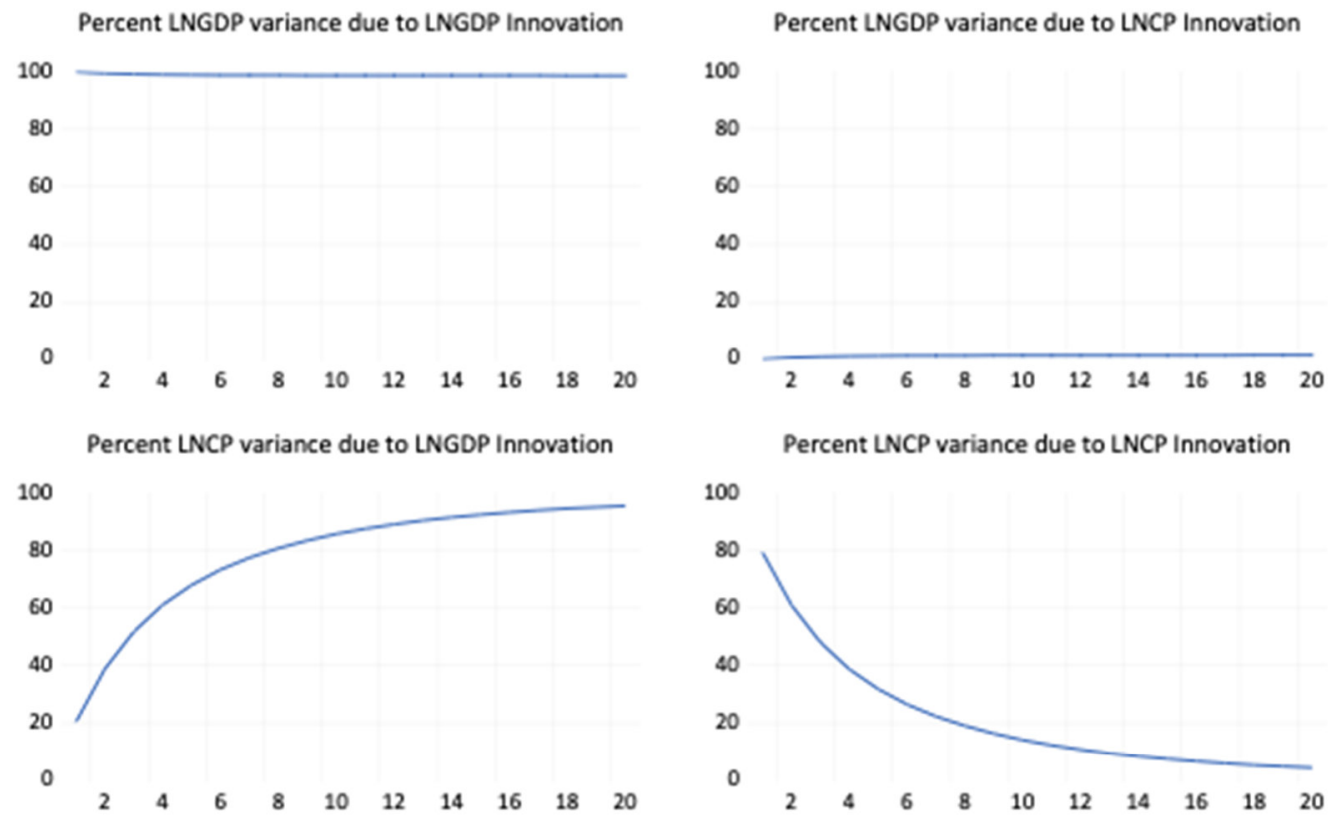

Variance Decomposition using Cholesky (d.f. adjusted) Factors
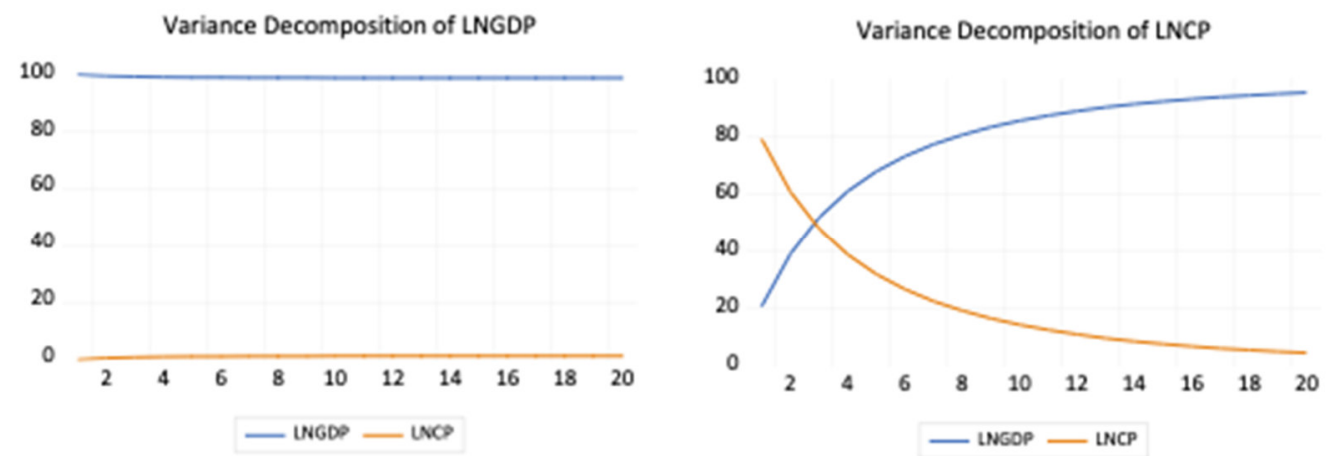

Variance Decomposition using Cholesky (d.f. adjusted) Factors

Variance Decomposition of LNGDP

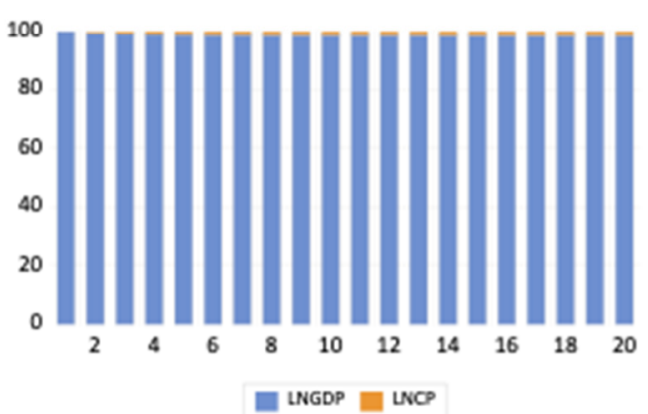

Variance Decomposition of LNCP

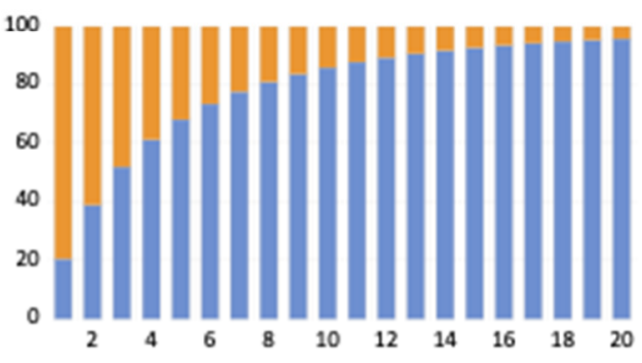

UNGOP

\subsubsection{Response Functions (IRFs)}

(Appendix 4.9, Appendix 4.10.1, Appendix 4.10.2, Figure 1: Responses of lngdp to lngdp, Figure 2: Responses of lngdp to lncp, Figure 3: Responses of lncp to lngdp, and Figure 4: Responses of $\operatorname{lncp}$ to $\operatorname{lncp}$ ). All the figures are on the next page.

In Figure 1, the change in its own shocks, which are positive and not fading, prompted the lngdp to respond in real time. The implication, therefore, is that a one standard deviation shock, impulse, or innovation given to 
lngdp will result in an increase in lngdp for all the 20 periods, without exceptions. The response of lngdp does not show a meaningful response to orthogonal changes in lncp. While the response of lngdp to lncp is statistically insignificant, it does show a positive trend throughout as shown in Figure 2.

Overall, lngdp shows a positive response to innovations in both lngdp and lncp. However, a greater positive response is seen with innovations in lngdp throughout the 20 periods (Figure 5: Responses of lngdp to Innovations).

Figure 3 shows how lncp responds to innovations in lngdp with a positive, instantaneous, and non-dissipating trend. This indicates that the lncp (crude oil prices) would continue to increase, inducing inflation in the long-run, until the government adopts a contractionary or a deflationary policy in response to induce a recessionary phase (cut down on economic activity by decreasing the lngdp); since, the recessionary phase trades-off increased rates of inflation, the government would have to conduct a cost-benefit analysis to deduce which action would reduce the marginal opportunity cost the most. Whereas, in Figure 4 a one standard deviation shock, impulse, or innovation given to lncp will result in a decrease in lncp until the 2 nd period, whereas from the 2 nd period forth it would result in an increase in the lngdp. The dropped lncp due to innovations in lncp till the 2 nd period demonstrates a tendency of achieving normality in the short run.

Overall, lncp shows a positive response in short run to, only, lngdp, and a negative response to, only, lncp. However, lncp shows a positive response to both lngdp and lncp in the long run.

Response to Cholesky One S.D. (d.f. adjusted) Innovations

-2 analytic asymptotic S.E.S

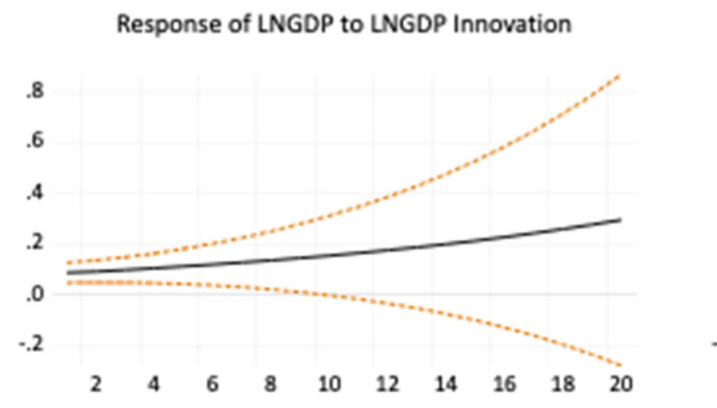

Response of LNCP to LNGDP Innovation

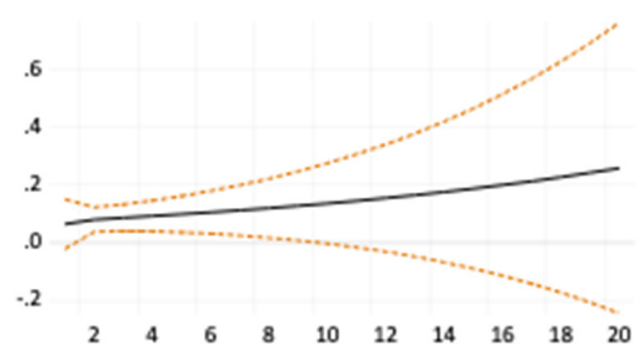

Response to Cholesky One S.D. (d.f. adjusted) Innovations

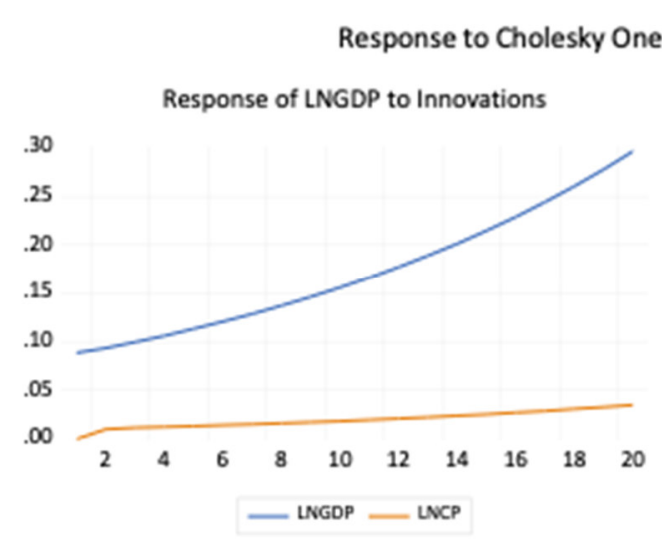

Response of LNGDP to LNCP Innovation

$$
\begin{aligned}
& .8 \\
& .6 \\
& .4 \\
& .2 \\
& .0
\end{aligned}
$$$$
\begin{array}{llllllllll}
2 & 4 & 6 & 8 & 10 & 12 & 14 & 16 & 18 & 20
\end{array}
$$

Response of LNCP to LNCP Innovation

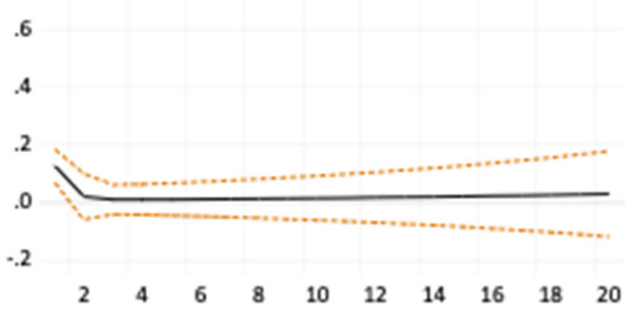

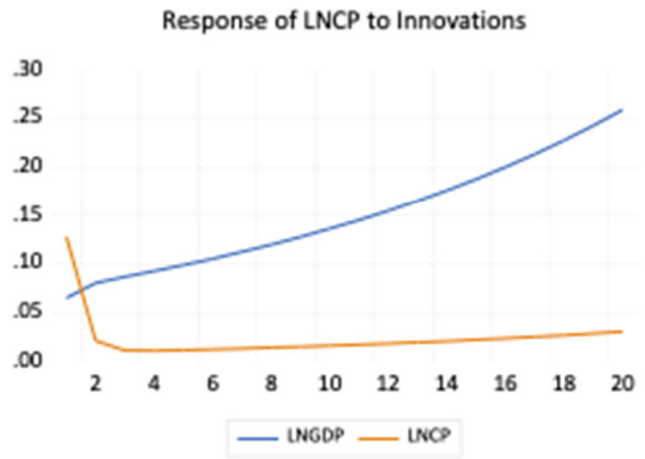




\subsection{Conclusion and Reccomendation}

The scope of this study is to develop a direct relationship between oil prices and Nigerian economic activity. We were able to demonstrate that crude oil prices had a statistically negligible impact on economic activity. Economic activity, on the other hand, has a positive and considerable influence on oil prices. Nigeria is a well-known truth that it is both an oil-producing and non-oil-producing economy. Oil income is one of the main sources of funding for the import. As an oil-producing economy, there are tendencies of having Dutch disease syndrome and economic pass-through.5

According to both theoretical and empirical assessments, Nigerian economic activity is a significant determinant of global crude prices; crude prices are intimately correlated to inflationary or deflationary impulses, and hence are affected by government policies on economic activity in Nigeria.

As a result, when policymakers enact policies relating to the aggregate level of economic activity, they should pay heed to the aggregate price level and external commodity markets, which can be accomplished by simultaneously measuring the domestic market and the economies of the country's trading partners. To avoid the Dutch illness syndrome, the economy should be diversified away from oil and toward non-oil industries.

\subsection{Appendix}

\subsection{Data Sets}

\begin{tabular}{|l|l|l|l|l|}
\hline Year & $\begin{array}{l}\text { Nominal } \\
\text { GDP/billions\$ }\end{array}$ & In(GDP) & $\begin{array}{l}\text { Nominal Crude } \\
\text { Oil Prices/\$ }\end{array}$ & In(CP) \\
\hline 1998 & 54.604 & 24.75934549 & 12.28 & 2.507971923 \\
\hline 1999 & 59.373 & 24.80710541 & 17.44 & 2.858766418 \\
\hline 2000 & 69.449 & 24.96385851 & 27.60 & 3.317815773 \\
\hline 2001 & 74.030 & 25.02773625 & 23.12 & 3.140698044 \\
\hline 2002 & 95.386 & 25.28119765 & 24.36 & 3.192942443 \\
\hline 2003 & 104.912 & 25.37638774 & 28.10 & 3.335769576 \\
\hline 2004 & 136.386 & 25.63875494 & 36.05 & 3.584906864 \\
\hline 2005 & 176.134 & 25.89451091 & 50.59 & 3.923753928 \\
\hline 2006 & 236.104 & 26.18753822 & 61.00 & 4.110873864 \\
\hline 2007 & 275.626 & 26.34231071 & 69.04 & 4.234686047 \\
\hline 2008 & 337.036 & 26.54345559 & 94.10 & 4.544358047 \\
\hline
\end{tabular}
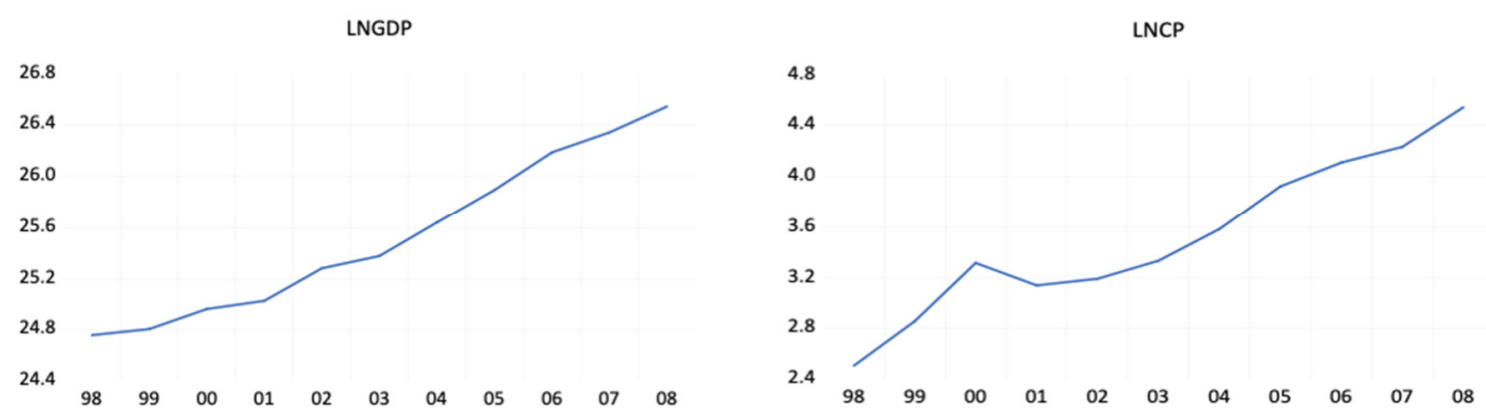
4.2.1 VAR Lag Order Selection Criterion for Ingdp Endogenous Variables: lngdp

Exogenous Variables: c

Sample: 19982008

Included observatons: 9

$\begin{array}{ccccccc}\text { Lag } & \text { LogL } & \text { LR } & \text { FPE } & \text { AIC } & \text { SC } & \text { HQ } \\ 0 & -7.314080 & \text { NA } & 0.371806 & 1.847573 & 1.869487 & 1.800283 \\ 1 & 10.90410 & 28.33939^{\circ} & 0.008156^{\circ} & -1.978689^{*} & -1.934862^{*} & -2.073269^{\circ} \\ 2 & 11.44933 & 0.726968 & 0.009196 & -1.877629 & -1.811887 & -2.019499\end{array}$

- indicates lag order selected by the criterion

LR: sequental moditied LR tesi statistic (each test at $5 \%$ level)

FPE: Final prediction error

AIC: Akake intormation criterion

SC: Schwarz information critenon

$\mathrm{HO}$ : Hannan-Quinn information critenon

*indicates lag order selected by the criterion.

4.2.2 VAR Lag Order Selection Criterion for Incp

Endogenous Variables: lncp

Exogenous Variables: c

Sample: 19982008

Included observations: 9
Lag
LOQL
LR
FPE
AIC
SC
$\mathrm{HQ}$

$\begin{array}{lr}0 & -6.175986 \\ 1 & 2.965519 \\ 2 & 2.965552\end{array}$

\section{NA}
0.288722
1.594664
$1.616577, \quad 1.547374$
$4.42 \mathrm{e}-0.5$
0.060583
0.007655
$0.073397-0.134215$

- indicates lag order selected by the criterion

LA: seguential moditied LR tesi statistic (each test at $5 \%$ level)

FPE: Final prediction error

AIC: Akake information criterion

SC: Schwarz intormation criterion

HO: Hannan-Quinn information critenon

*indicates lag order selected by the criterion.

4.3 Vector Autoregression Estimates

Sample (adjusted): 19992008

Included observations: 10 after adiustments

Standard errors in \langle\rangle $\& \mathbf{\&}$-statistics in |

LNGDP LNCP

\begin{tabular}{|c|c|c|}
\hline LNGDP(-1) & $\begin{array}{c}0.997732 \\
\langle 0.18286| \\
|5.45624|\end{array}$ & $\begin{array}{r}0.787114 \\
\langle 0.29706\rangle \\
|2.64971|\end{array}$ \\
\hline $\operatorname{LNCP}(-1)$ & $\begin{array}{c}0.078308 \\
\langle 0.18920\rangle \\
|0.41389|\end{array}$ & $\begin{array}{r}0.167067 \\
\langle 0.30735\rangle \\
|0.54357|\end{array}$ \\
\hline C & $\begin{array}{c}-0.031800 \\
\langle 4.03340\rangle \\
|-0.00788|\end{array}$ & $\begin{array}{r}-16.96170 \\
\langle 6.55225\rangle \\
|-2.58868|\end{array}$ \\
\hline $\begin{array}{l}\text { A-squared } \\
\text { Adj. H-squared } \\
\text { Sum sq. resids } \\
\text { S.E. equation } \\
\text { F-statistic } \\
\text { Loa likelihood } \\
\text { Akaike AlC } \\
\text { Schwarz SC } \\
\text { Mlean dependent } \\
\text { S.D. dependent }\end{array}$ & $\begin{array}{r}0.983835 \\
0.979216 \\
0.054747 \\
0.088436 \\
213.0125 \\
11.84875 \\
-1.769749 \\
-1.678974 \\
25.60629 \\
0.613429\end{array}$ & $\begin{array}{l}0.947083 \\
0.931964 \\
0.144476 \\
0.143664 \\
62.64110 \\
6.996765 \\
-0.799353 \\
-0.708578 \\
3.624457 \\
0.550779\end{array}$ \\
\hline \multicolumn{2}{|c|}{ 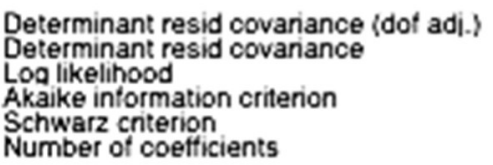 } & $\begin{array}{c}0.000128 \\
6.28 \mathrm{E}-05 \\
20.00027 \\
-2.800054 \\
-2.618503 \\
6\end{array}$ \\
\hline
\end{tabular}


4.4.1 Augmented Dickey-Fuller Unit Root Test in Level on D[InGDP], Included in Test Equation: Intercept Null Hypothesis: LNGDP has a unit root

Exogenous: Constant

Laq Length: O (Automatc - based on AIC, maxiaq=1)

1-Statistic Prob.:

Auqmented Dickey-Fuller test statistc

Test cribcal values: $\quad 1 \%$ level

$1.431777 \quad 0.9968$

$5 \%$ level

$-4.297073$

$10 \%$ leve

$-3.212696$

$-2.747676$

-Mackinnon (1996) one-sided p-values.

Warning: Probabilites and cntical values calculated for 20 observations and may not be aocurate for a sample size of 10

Sample (adiusted): 19992008

Included observations: 10 atter adjustments

$\begin{array}{crrrl}\text { Variable } & \text { Coefficient } & \text { Std. Error } & \text { 1-Statistic } & \text { Prob. } \\ \text { LNGDP(-1) } & 0.070309 & 0.049106 & 1.431777 & 0.1901 \\ C & -1.609386 & 1.248937 & -1.288605 & 0.2335\end{array}$

$\begin{array}{lllr}\text { R-squared } & 0.203979 & \text { Mean dependent var } & 0.178411 \\ \text { Adusted R-squared } & 0.104476 & \text { S.D. dependent var } & 0.088480 \\ \text { S.E. of regression } & 0.083730 & \text { Akaike info cnterion } & -1.945572 \\ \text { Sum squared resid } & 0.056086 & \text { Schwarz critenon } & -1.885055 \\ \text { Log likelinocd } & 11.72786 & \text { Hannan-Quinn criter. } & -2.011959 \\ \text { F-statsbc } & 2.049984 & \text { Durbin-Watson stat } & 2.504555 \\ \text { Prob(F-statistic) } & 0.190095 & & \end{array}$

4.4.2 Augmented Dickey-Fuller Unit Root Test in Level on D[InGDP], Included in Test Equation: Trend and Intercept

Null Hypothesis: LNGDP has a unit root

Exogenous: Constant, Linear Trend

Laq Length: O (Automabc - based on AIC, maxlaq=2)

\begin{tabular}{|c|c|c|}
\hline & 1-Statistic & Prob.: \\
\hline $\begin{array}{l}\text { Augmented Dickev-Fuller test statsoc } \\
\begin{array}{ll}1 \% \text { level } \\
\text { Test critcal values: } & 5 \% \text { level } \\
& 10 \% \text { level }\end{array}\end{array}$ & $\begin{array}{r}-2.338137 \\
-5.295384 \\
-4.008157 \\
-3.460791\end{array}$ & 0.3813 \\
\hline
\end{tabular}

- Mackinnon (1996) one-sided p-values.

Warning: Probabilites and cntical values calculated for 20 observatons a may not be accurate tor a sample size of 10 
Sample (adiusted): 19992008

Included observations: 10 atter adjustments

$\begin{array}{crrrl}\text { Vanable } & \text { Coeflicient } & \text { Std. Error } & \text { 1-Statistic } & \text { Prob. } \\ \text { LNGDP(-1) } & -0.486410 & 0.208033 & -2.338137 & 0.0520 \\ \text { (. } & 11.96287 & 5.078583 & 2.355552 & 0.0507 \\ \text { فTREND'"1998') } & 0.106168 & 0.039053 & 2.718540 & 0.0298\end{array}$

$\begin{array}{lllr}\text { R-squared } & 0.612789 & \text { Mean dependent var } & 0.178411 \\ \text { Adusted R-squared } & 0.502157 & \text { S.D. dependent var } & 0.088480 \\ \text { S.E. of regression } & 0.062430 & \text { Akaike info cnterion } & -2.466227 \\ \text { Sum squared resid } & 0.027282 & \text { Schwarz critenon } & -2.375451 \\ \text { Log likeincod } & 15.33113 & \text { Hannan-Quinn criter. } & -2.565807 \\ \text { F-stabstcc } & 5.538992 & \text { Durbin-Watson stat } & 2.720731 \\ \text { Prob(F-statistc) } & 0.036126 & & \end{array}$

4.4.3 Augmented Dickey-Fuller Unit Root Test in 1st Level on D[InGDP], Included in Test Equation: Intercept

Null Hypothesis: DILNGDPI has a unit root

Exogenous: Constant

Laq Length: $O$ (Automatic - based on AIC, maxlaq=2)

\begin{tabular}{|c|c|}
\hline & 1-Statistic \\
\hline $\begin{array}{ll}\text { Augmented Dickev-Fuller test statistic } \\
\text { Test critcal values: } & 1 \% \text { level } \\
& 5 \% \text { level } \\
& 10 \% \text { level }\end{array}$ & $\begin{array}{r}-3.269602 \\
-4.420595 \\
-3.259808 \\
-2.771129\end{array}$ \\
\hline
\end{tabular}

- MacKinnon (1996) one-sided p-values.

Warning: Probabilites and cntical values calculated for 20 observabons a may not be accurate for a sample size of 9

Sample (adiusted): 20002008 Included observations: 9 atter adjustments

$\begin{array}{ccccc}\text { Vanable } & \text { Coefficient } & \text { Std. Error } & \text { 1-Statistic } & \text { Prob. } \\ \text { DiLNGDP(-1) } & -1.058331 & 0.323688 & -3.269602 & 0.0137 \\ \text { C } & 0.203187 & 0.063677 & 3.190892 & 0.0153\end{array}$

R-squared
Adusted R-squared
S.E. of regression
Sum squared resid
Loq likelinood
F-statsoc
Probif-statisto)

0.604303
0.547775
0.085569
0.051254
10.48637
10.69030
0.013682

Mean decendent var S.D. dependent var Akaike info cnterion Schwarz critenon Hannan-Quinn criter. Durbin-Watson stat
0.017043

0.127244

$-1.885861$

$-1.842033$

$-1.980441$

2.134002

4.4.4 Augmented Dickey-Fuller Unit Root Test in 1st Level on D[InGDP], Included in Test Equation: Trend and Intercept

Null Hypothesis: DILNGDPI has a unit root

Exogenous: Constant, Linear Trend

Laq Length: 0 (Automatic - based on AIC, maxlaq=2)

\section{Augmented Dickev-Fuller test stabstoc \\ Test critcal values: $1 \%$ level \\ $5 \%$ level \\ $10 \%$ level}

1-Statistic Prob:

$-3.834388$

$-5.521860$

$-4.107833$

$-3.515047$

0.0692

-Mackinnon (1996) one-sided p-values.

Warning: Probabilites and cntical values calculated for 20 observatons a may not be accurate tor a sample size of 9 
Sample (adiusted): 20002008 Included observations: 9 atter adjustments

\begin{tabular}{|c|c|c|c|c|}
\hline Vanable & Coefticient & Sid. Error & 1-Statistic & Prob. \\
\hline 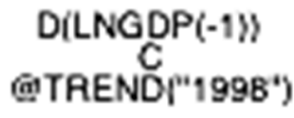 & $\begin{array}{r}-1.407603 \\
0.145508 \\
0.019852\end{array}$ & $\begin{array}{l}0.367100 \\
0.068265 \\
0.012528\end{array}$ & $\begin{array}{r}-3.834388 \\
2.131524 \\
1.584541\end{array}$ & $\begin{array}{l}0.0086 \\
0.0770 \\
0.1642\end{array}$ \\
\hline $\begin{array}{l}\text { ared } \\
\text { ed R-squared } \\
\text { f rearession } \\
\text { quared resid } \\
\text { eelino } \\
\text { stoc } \\
\text { f-stabsto) }\end{array}$ & $\begin{array}{l}0.721038 \\
0.628051 \\
0.077603 \\
0.036134 \\
12.05945 \\
7.754149 \\
0.021709\end{array}$ & \multicolumn{2}{|c|}{$\begin{array}{l}\text { Mean dependent var } \\
\text { S.D. dependent var } \\
\text { Akaike info cnterion } \\
\text { Schwarz critenon } \\
\text { Hannan-Quinn criter. } \\
\text { Durbin-Watson stat }\end{array}$} & $\begin{array}{r}0.017043 \\
0.127244 \\
-2.013212 \\
-1.947470 \\
-2.155082 \\
1.725627\end{array}$ \\
\hline
\end{tabular}

4.5 VAR Residual Serial Correlation LM Test Sample: 19982008 Included observations: 10

Null hypothesis: No serial correlation at lag $h$
Laq
LRE* stat
Prob. Rao F-stat
dit
Prob.
1
1.729037
$0.7854 \quad 0.423620$
(4. 8.0)
0.7879

Null hypothesis: No serial correlatoon at lags 1 to $\mathrm{h}$

$\begin{array}{ccccccc}\text { Laq } & \text { LRE' stat } & \text { d } & \text { Prob. } & \text { Rao F-stat } & \text { di } & \text { Prob. } \\ 1 & 1.729037 & 4 & 0.7854 & 0.423620 & (4.8 .0) & 0.7879\end{array}$

-Edgeworth expansion corrected likelihood rabo stabistc.

4.6.1 VAR Granger Causality/Block Exogeneity Wald Tests Sample: 19982008

Included observations: 10

Dependent variable: LNGDP

$\begin{array}{cccc}\text { Excluded } & \text { Chi-sq } & \text { at } & \text { Prob. } \\ \text { LNCP } & 0.171306 & 1 & 0.6790 \\ \text { All } & 0.171306 & 1 & 0.6790\end{array}$

Dependent variable: LNCP

$\begin{array}{cccc}\text { Excluded } & \text { Chi-sq } & \text { at } & \text { Prob. } \\ \text { LNGDP } & 7.020970 & 1 & 0.0081 \\ \text { All } & 7.020970 & 1 & 0.0081\end{array}$

4.6.2 Pairwise Granger Causality Test Sample: 19982008 Laas: 1

Null Hypothesis:

Obs F-Statistic Prob.

LNCP does not Granaer Cause LNGDP

LNGDP does not Granaer Cause LNCP

$\begin{array}{lll}10 & 0.17131 & 0.6913 \\ & 7.02097 & 0.0330\end{array}$




\subsection{Normality Test \\ Sample: 19982008}

included observatons: 10

$\begin{array}{ccccc}\text { Component } & \text { Skewness } & \text { Chi-sq } & \text { at } & \text { Prob. } \\ 1 & 0.026746 & 0.001192 & 1 & 0.9725 \\ 2 & 1.212289 & 2.449409 & 1 & 0.1176 \\ \text { Joint } & & 2.450601 & 2 & 0.2937 \\ \text { Component } & \text { Kurtosis } & \text { Chi-sq } & \text { at } & \text { Prob. } \\ 1 & 1.353285 & 1.129862 & 1 & 0.2878 \\ 2 & 3.914655 & 0.348580 & 1 & 0.5549 \\ \text { Joint } & & 1.478443 & 2 & 0.4775 \\ \text { Component } & \text { Jarque-Bera } & \text { at } & \text { Prob. } & \\ 1 & 1.131055 & 2 & 0.5681 & \\ 2 & 2.797989 & 2 & 0.2468 & \\ \text { Joint } & 3.929044 & 4 & 0.4157 & \end{array}$

"Approximate p-values do not account for coetficient estimation

4.8 VAR Residual Heteroskedasticity Test Sample: 19982008

$\begin{array}{lccccc}\begin{array}{c}\text { Joint test: } \\ \text { Chi-sq }\end{array} & \text { di } & \text { Prob. } & & & \\ 13.91153 & 12 & 0.3064 & & & \\ & & & & & \\ \text { Individual components: } & & & & \\ \text { Dependent } & \text { R-squared } & \text { F(4.5) } & \text { Prob. } & \text { Chi-sqi4) } & \text { Prob. } \\ \text { res1"res1 } & 0.610830 & 1.961965 & 0.2388 & 6.108302 & 0.1912 \\ \text { res2"res2 } & 0.469759 & 1.107418 & 0.4452 & 4.697588 & 0.3198 \\ \text { res2"res1 } & 0.061371 & 0.081729 & 0.9845 & 0.613705 & 0.9615\end{array}$

4.9 Variance Decomposition using Cholesky (d.f. Adjusted) Factors

\begin{tabular}{|c|c|c|c|}
\hline $\begin{array}{l}\text { Variance } \\
\text { Penod }\end{array}$ & $\begin{array}{l}\text { mposition of } \\
\text { S.E. }\end{array}$ & GDP: & LNCP \\
\hline $\begin{array}{l}1 \\
2 \\
3 \\
4 \\
5 \\
6 \\
7 \\
7 \\
9 \\
10 \\
11 \\
12 \\
13 \\
14 \\
15 \\
16 \\
17 \\
19 \\
19 \\
20\end{array}$ & $\begin{array}{l}0.088436 \\
0.128975 \\
0.163275 \\
0.195079 \\
0.225863 \\
0.256411 \\
0.287223 \\
0.318656 \\
0.350990 \\
0.384463 \\
0.419286 \\
0.455657 \\
0.493764 \\
0.533796 \\
0.575940 \\
0.620387 \\
0.667335 \\
0.716987 \\
0.769557 \\
0.825268\end{array}$ & $\begin{array}{l}100.0000 \\
99.39600 \\
99.11186 \\
98.96424 \\
98.87603 \\
98.8794 \\
98.77710 \\
98.77703 \\
98.72414 \\
98.70626 \\
98.69201 \\
98.68048 \\
98.67103 \\
98.66320 \\
98.65665 \\
98.65114 \\
98.64648 \\
98.64251 \\
98.63911 \\
98.63620\end{array}$ & $\begin{array}{l}0.0000000 \\
0.603939 \\
0.868141 \\
1.035760 \\
1.123967 \\
1.182057 \\
1.222902 \\
1.252970 \\
1.275862 \\
1.293742 \\
1.307986 \\
1.319519 \\
1.328972 \\
1.336803 \\
1.343348 \\
1.348656 \\
1.353521 \\
1.357492 \\
1.360887 \\
1.363600\end{array}$ \\
\hline $\begin{array}{l}\text { Variance } \\
\text { Penod }\end{array}$ & $\begin{array}{l}\text { nposition of } \\
\text { S.E. }\end{array}$ & ${ }_{\text {CP }} \dot{\text { HNOP }}$ & LNCP \\
\hline $\begin{array}{l}1 \\
2 \\
3 \\
4 \\
5 \\
6 \\
7 \\
7 \\
9 \\
10 \\
11 \\
12 \\
13 \\
14 \\
15 \\
16 \\
17 \\
19 \\
19 \\
20\end{array}$ & $\begin{array}{l}0.143664 \\
0.166067 \\
0.187791 \\
0.209759 \\
0.232223 \\
0.255374 \\
0.279375 \\
0.304373 \\
0.330504 \\
0.355905 \\
0.386706 \\
0.417042 \\
0.449050 \\
0.48277 \\
0.518652 \\
0.556545 \\
0.596711 \\
0.639320 \\
0.684549 \\
0.732569\end{array}$ & $\begin{array}{l}20.62222 \\
38.93626 \\
51.87416 \\
61.14647 \\
68.04482 \\
73.336652 \\
77.49364 \\
80.82675 \\
83.52364 \\
85.74616 \\
87.59194 \\
89.13753 \\
90.44072 \\
91.54993 \\
92.48783 \\
93.29405 \\
93.98651 \\
94.56313 \\
95.09855 \\
95.54463\end{array}$ & $\begin{array}{l}79.37778 \\
61.06374 \\
48.12584 \\
38.85353 \\
31.95518 \\
26.66338 \\
22.50636 \\
19.17925 \\
16.47636 \\
14.25384 \\
12.40806 \\
10.86247 \\
9.559282 \\
8.454069 \\
7.512124 \\
6.705949 \\
6.013491 \\
5.416870 \\
4.901455 \\
4.455168\end{array}$ \\
\hline $\begin{array}{l}\text { Cholesky } \\
\text { Cholesky }\end{array}$ & NGD & & \\
\hline
\end{tabular}




\subsubsection{Response Functions (IRFs) for Ingdp}

\begin{tabular}{|c|c|c|}
\hline $\begin{array}{l}\text { Respor } \\
\text { Period }\end{array}$ & $\begin{array}{l}\text { NGDP: } \\
\text { LNGDP }\end{array}$ & LNCP \\
\hline 1 & 0.088436 & 0.000000 \\
\hline 2 & $\begin{array}{l}10.01977) \\
0.093344\end{array}$ & $\begin{array}{l}(0.00000) \\
0.010023\end{array}$ \\
\hline 3 & 0.021831 & $\begin{array}{l}(0.02432) \\
0.011675\end{array}$ \\
\hline 4 & $\begin{array}{l}0.024941 \\
0.106018 \\
(0.0216\end{array}$ & $\begin{array}{l}0.028111 \\
0.012546 \\
00.03012\end{array}$ \\
\hline 5 & 0.113044 & $\begin{array}{l}0.013387 \\
(0.03205)\end{array}$ \\
\hline 6 & 0.120536 & $\begin{array}{l}0.014275 \\
0.034101\end{array}$ \\
\hline 7 & 0.128525 & $\begin{array}{l}0.015222 \\
(0.03628)\end{array}$ \\
\hline 8 & $\begin{array}{l}0.137044 \\
(0.05732)\end{array}$ & $\begin{array}{l}0.016230 \\
(0.03863)\end{array}$ \\
\hline 9 & $\begin{array}{l}0.146127 \\
(0.06727)\end{array}$ & 0.017306 \\
\hline 10 & 0.155812 & 0.018453 \\
\hline 11 & 0.166138 & 0.019676 \\
\hline 12 & 0.177150 & 0.02098 \\
\hline 13 & 0.188891 & 0.02237 \\
\hline 14 & $\begin{array}{l}0.201410 \\
(0.13803)\end{array}$ & $\begin{array}{l}0.023853 \\
(0.05676)\end{array}$ \\
\hline 15 & 0.214759 & $\begin{array}{l}0.025434 \\
(0.06061)\end{array}$ \\
\hline 16 & 0.228993 & 0.027120 \\
\hline 17 & 70 & 28918 \\
\hline 18 & 3 & 23083 \\
\hline 19 & 89 & 23287 \\
\hline 20 & $\begin{array}{l}0.296008 \\
(0.28687)\end{array}$ & $\begin{array}{r}0.035057 \\
(0.08467)\end{array}$ \\
\hline
\end{tabular}

4.10.2 Response Functions (IRFs) for Incp

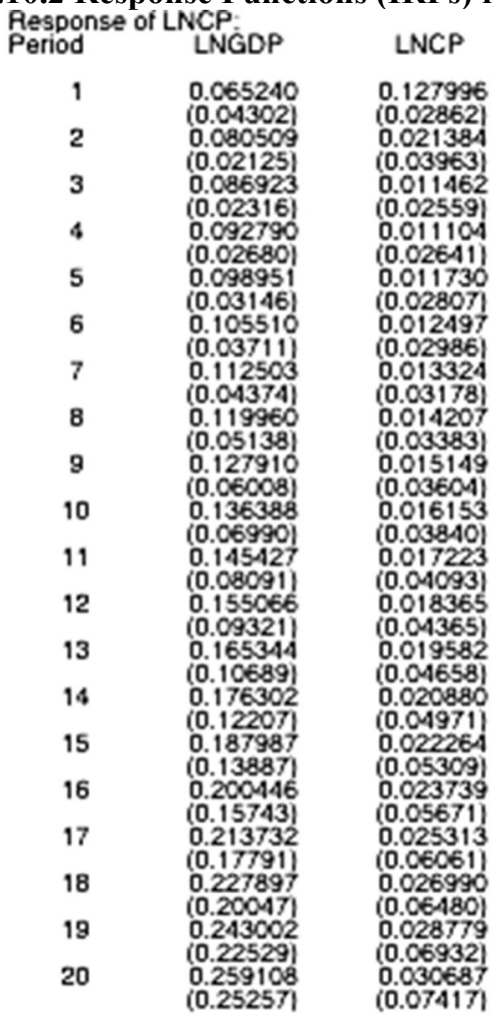

Cholesky One S.D. (d.f. adjusted

Cholesky ordering: LNGD
Standard errors: Analyic 


\subsection{References}

1. Omoregie, Uyiosa (2018). Nigeria's Petroleum Sector and GDP - The Missing Oil Refining Link. Retrieved from https://ideas.repec.org/p/osf/socarx/5raqk.html

2. Mikalauskiene, Ciegis, Nakciunaite (2013). Dependence between Labor Market and Economic Cycles. Retrieved https://www.researchgate.net/publication/277417941_Dependence between_Labour_Market and Economi c Cycles

3. Žalgirytè, Gižienè (2014). The analysis of trends in GDP and cyclical nature of GDP changes in Baltic states. Retrieved from https://cyberleninka.org/article/n/1355134/viewer

4. Gylych, Jibrin, Celik, Isik (2020). Impact of Oil Price Fluctuation on the Economy of Nigeria, the Core Analysis for Energy Producing Countries. Retrieved from https://www.intechopen.com/online-first/73798DOI: 10.5772/intechopen.94055

5. Corden WM, Neary JP (1982). Booming sector and De-industrialization in a small open economy. 825-848. Retrieved from https://academic.oup.com/ej/article/92/368/825/5220457.

DOI: $10.2307 / 2232670$

\subsection{Author}

Siddhant Jhawar, the author of this research paper, is at the moment a rising junior in Daly College, Indore. He is highly fervent about disciplines involving mathematics, psychology, and economics. He plans on continuing the existing research for his future endeavors. 